\title{
Pengaruh Rasio Profitabilitas Terhadap Harga Saham Pada Perusahaan Rokok Yang Terdaftar Di Bursa Efek Indonesia
}

\author{
Nurlia \\ Program Studi Manajemen Fakultas Ekonomi \\ Universitas Balikpapan \\ Jl. Pupuk Raya Po Box 335 Balikpapan. Telp./Fax. 0542-764205 \\ Email : Nur2286@Gmail.Com
}

\begin{abstract}
This Study Takes The Object Cigarette Company Listed On The Indonesia Stock Exchange. Population And Sample In This Research Is All Cigarette Companies Listed On The Indonesia Stock Exchange, Pt Hm Sampoerna, Pt Bentoel International Investama And Pt Gudang Garam. The Samples In This Study Using Total Sampling. Data Retrieved Are Secondary Data From The Financial Statements Of The Company For A Certain Period In Which The Financial Statements Are Derived From Data Gathered In The Indonesian Stock Exchange Were Then Analyzed Using Spss Version 17 For Windows. Data Collection Techniques By Means Of Documentation And Literature Study. Based On The Results Of Data Analysis Known That Profitability Ratios Simultaneously Significant Effect On Stock Prices At Cigarrete Company Listed On The Indonesia Stock Exchange. This Is Evidenced By The Results Of The Test Analysis F F Count Has A Value That Has A Significance Level Of Less Than 0.05. Based On The Analysis Of Data Obtained T Value Variable Earning Per Share Has A Significance Level Of Less Than 0.05, Thus It Can Be Said That Partial Earnings Per Share Significantly Influence Stock Prices. While The Variable That Consists Of Operating Profit Margin, Net Profit Margin, Return On Assets And Return On Equity Have A Significance Level Greater Than 0.05 So That The Partial Operating Profit Margin, Net Profit Margin, Return On Assets And Return On Equity Has No Effect On Share Price On Cigarette Companies Listed On The Indonesia Stock Exchange.
\end{abstract}

Key Words :Profitability Ratio, Stock Price, Operating Profit Margin, Net Profit Margin.

\begin{abstract}
Abstrak
Penelitian Ini Mengambil Objek Perusahaan Rokok Yang Terdaftar Di Bursa Efek Indonesia. Populasi Dan Sampel Dalam Penelitian Ini Adalah Seluruh Perusahaan Rokok Yang Terdaftar Di Bursa Efek Indonesia Yaitu Pt Hm Sampoerna, Pt Bentoel Internasional Investama, Dan Pt Gudang Garam. Pengambilan Sampel Dalam Penelitian Ini Menggunakan Total Sampling.Data Diambil Adalah Data Sekunder Berupa Laporan Keuangan Perusahaan Dalam Periode Tertentu Dimana Laporan Keuangan Yang Diperoleh Berasal Dari Data Di Bursa Efek Indonesia Selanjutnya Dianalisis Dengan Menggunakan Spss Versi 17 For Windows. Teknik Pengumpulan Data Dengan Cara Dokumentasi Dan Studi Kepustakaan.Berdasarkan Hasil Analisis Data Diketahui Bahwa Rasio Profitabilitas Secara Simultan Berpengaruh Signifikan Terhadap Harga Saham Pada Perusahaan Rokok Yang Terdaftar Di Bursa Efek Indonesia. Hal Ini Dibuktikan Dengan Hasil Analisis Uji F Yang Mempunyai Nilai F Hitung Yang Mempunyai Tingkat Signifikansi Kurang Dari 0,05.Berdasarkan Hasil Analisis Data Diperoleh Nilai T Hitung Variabel Earning Per Share Mempunyai Tingkat Signifikansi Kurang Dari 0,05, Dengan Demikian Dapat Dikatakan Bahwa Secara Parsial Earning Per Share Berpengaruh Signifikan Terhadap Harga Saham. Sedangkan Variabel Yang Terdiri Dari Operating Profit Margin, Net Profit Margin, Return On Asset Dan Return On Equity Mempunyai Tingkat Signifikansi Lebih Besar Dari 0,05 Sehingga Secara Parsial Operating Profit Margin, Net Profit Margin, Return On Asset Dan Return On Equity Tidak Berpengaruh Terhadap Harga Saham Pada Perusahaan Rokok Yang Terdaftar Di Bursa Efek Indonesia.
\end{abstract}

Kata Kunci : Profitabilitas Rasio, Harga Saham, Selisih Keuntungan Operasi, Selisih Keuntungan Bersih. 


\section{Pendahuluan}

Dalam mengembangkan usahanya, perusahaan selalu dihadapkan kepada persoalan bagaimana mendapatkan modal. Secara teoritis, ada banyak cara yang dapat ditempuh misalnya dengan cara meminjam dana kepada bank dalam jumlah yang besar atau dari investor. Namun demikian, cara ini dinilai memiliki resiko yang tinggi serta beberapa kendala, antara lain kendala kurangnya akses terhadap investor itu sendiri maupun kendala lain termasuk kurangnya informasi mengenai kondisi keuangan perusahaan.

Seorang investor yang rasional sebelum mengambil keputusan melakukan investasi atau tidak, umumnya memperhatikan dua hal yaitu pendapatan yang diharapkan (expected return) dan tingkat resiko (risk) yang terkandung dari alternatif investasi yang dilakukan. Terhadap dua pertimbangan itu, intinya investor bersedia menginvestasikan dana atau hartanya hanya kepada perusahaan yang diyakini memiliki kinerja keuangan yang baik. Atas dasar inilah maka suatu perusahaan wajib menempatkan perihal kinerja keuangan yang baik itu sebagai persyaratan penting untuk menarik pihak investor.

Kondisi keuangan perusahaan dapat dilihat dari laporan keuangan perusahaan yang diterbitkan perusahaan secara berkala. Sebab, dalam setiap laporan keuangan perusahaan dapat diperoleh informasi tentang posisi keuangan perusahaan, kinerja keuangan, aliran kas perusahaan, dan informasi lain yang sangat berkaitan dengan laporan keuangan. Laporan keuangan yang berupa neraca, laporan laba rugi dari suatu perusahaan, bila disusun secara baik dan akurat dapat memberikan gambaran keadaan yang nyata mengenai hasil atau prestasi yang telah dicapai oleh suatu perusahaan selama kurun waktu tertentu.

Pilihan perusahaan rokok sebagai objek penelitian penulis didasarkan kepada beberapa alasan antara lain, bahwa perusahaan rokok adalah perusahaan yang umumnya terdaftar di Bursa Efek Indonesia. Perusahaan rokok yang masuk di BEI tentunya telah memiliki laporan keuangan yang telah diaudit oleh akuntan publik dengan hasil audit yang bersifat wajar tanpa syarat (unqualified opinion). Hal penting pula, bahwa perusahaan yang masuk pasar modal melalui suatu bursa semisal Bursa Efek Jakarta tentunya adalah perusahaan yang memiliki informasi mengenai posisi keuangan perusahaan yang akurat dan mudah diakses oleh publik khususnya oleh para investor yang akan menanamkan sahamnya.

Berdasarkan uraian di atas, maka dapat dirumuskan permasalahan dalam penelitian iniapakah rasio profitabilitas secara simultan berpengaruh signifikan terhadap harga saham dan apakah Operating Profit Margin, Net Profit Margin, Return on Asset, Return on Equity, dan Earning per share secara parsial berpengaruh signifikan terhadap harga saham pada perusahaan rokok yang terdaftar di Bursa Efek Indonesia?

Adapun tujuan penelitian ini Untuk mengetahui pengaruh rasio profitabilitas secara simultan terhadap harga saham dan untuk mengetahui pengaruh Net Profit Margin, Operating Profit Margin, Return On Asset, Return On Equity, Earning Per Share secara parsial terhadap harga saham pada perusahaan rokok yang terdaftar di Bursa Efek Indonesia.

\section{Tinjauan Pustaka Saham}

Rusdin (2006:68) mendefinisikan saham adalah sertifikat yang menunjukkan bukti kepemilikan suatu perusahaan, dan pemegang saham memiliki hak klaim atas penghasilan dan aktiva perusahaan.

Menurut Darmadji dan Fakhruddin (2001:5), saham dapat didefinisikan sebagai :"tanda penyertaan atau kepemilikan seseorang atau badan dalam suatu perusahaan atau perseroan terbatas. Wujud saham adalah selembar kertas yang menerangkan bahwa pemilik kertas tersebut adalah pemilik perusahaan yang menerbitkan surat berharga tersebut. Porsi 
kepemilikan ditentukan oleh seberapa besar penyertaan yang ditanamkan di perusahaan tersebut".

\section{Analisa Rasio Keuangan}

Menurut Hampton (1997:110), rasio keuangan dapat digolongkan menjadi tiga kategori, yaitu sebagai berikut:

1) Rasio Likuiditas, bertujuan menguji kecukupan dana, solvency perusahaan, kemampuan perusahaan membayar kewajiban yang segera harus dipenuhi. Yang termasuk rasio likuiditas misalnya rasio lancar (current ratio), rasio tunai (quick ratio), perputaran piutang (receivable turnover), perputaran persediaan (inventory turnover).

2) Rasio Profitabilitas, bertujuan mengukur efisiensi aktivitas perusahaan dan kemampuan perusahaan untuk memperoleh keuntungan. Misalnya margin keuntungan (profit margin), margin laba bruto (gross profit margin), perputaran aktiva (operating asset turnover), imbalan hasil dari investasi (return on investment), rentabilitas modal sendiri (return on equity), dan sebagainya.

3) Rasio pemilikan, berkaitan langsung atau tidak langsung dengan keuntungan dari likuiditas. Membantu pemilik saham dalam mengevaluasi aktivitas dan kebijaksanaan perusahaan yang berpengaruh terhadap harga saham di pasaran.

\section{Rasio Profitabiltas}

Rasio Profitabilitas merupakan daya tarik utama dari perusahaan dan para pemegang perusahaan. Adapun Rasio Profitabilitas adalah sebagai berikut:

1) Operating Profit Margin, Menurut Agnes Sawir, (2005:33), yaitu rasio yang mengukur kemampuan perusahaan dalam menghasilkan laba kotor dari pendapatan usaha perusahaan tersebut.

2) Net Profit Margin (NPM), merupakan rasio yang menunjukkan kemampuan perusahaan untuk menghasilkan laba dibandingkan dengan penjualan yang dicapai dengan memperbandingkan antara laba bersih setelah pajak setelah penjulan bersih.

Menurut Agnes Sawir, (2005:33), mendefinisikan rasio net profit margin sebagai berikut : "Rasio net profit margin adalah rasio untuk mengukur kemampuan perusahaan dalam menghasilkan net income ditinjau dari sudut operatingincomenya. Semakin tinggi rasio maka makin baik hasil yang ditunjukkan".

3) Return On Invesment, menurut Susan Irawati (2006:63), mendefinisikan bahwa return on invesment adalah suatu cara untuk mengukur seberapa banyak laba bersih yang bisa diperoleh dari kekayaan yang dimiliki oleh perusahaan.

4) Return On Equity, menurut Lukman Syamsudin (2002:66) mendefinisikan bahwa return on equity adalah "Rasio untuk mengetahui seberapa besar tingkat pengembalian dana yang telah diinvestasikan dalam suatu perusahaan. Semakin tinggi tingkat ROE suatu perusahaan maka semakin baik tingkat pengembalian dari dana yang telah diinvestasikan"

5) Earning Per Share, menurut Munawir (2002:36), mengemukakan "Earning Per Share adalah keuntungan yang tersedia bagi pemegang saham biasa, keuntungan ini diperoleh setelah dikurangi deviden dan hak-hak lainnya untuk pemegang saham perioritas dengan cara membagi jumlah keuntungan yang tersedia bagi pemegang saham biasa dengan jumlah lembar saham biasa yang beredar akan diketahui keuntungan untuk setiap lembar saham".

6) Return On Assets(ROA)

Menurut Munawir (2004:89) berpendapat "Return on assets (ROA)adalahperbandingan antara laba bersih setelah pajak dan aktiva total perusahaan. 


\section{Hipotesis}

Adapun hipotesis yang diajukan yaitu variabel rasio profitabilitas secara simultan berpengaruh signifikan terhadap harga saham dan variabel operating profit margin, net profit margin, return on asset, return on equity dan earning per sharesecara parsial berpengaruh signifikan terhadap harga saham pada perusahaan rokok yang terdaftar di Bursa Efek Indonesia.

\section{Metode Penelitian}

\section{Variabel dan Definisi Operasional}

Untuk memudahkan pembahasan dalam penelitian ini, maka berikut penjabaran mengenai pengaruh Rasio Profitabilitas terhadap harga saham pada perusahaan rokok yang terdaftar di Bursa Efek Indonesia. Varibel dependen (Y) adalah harga saham sedangkan Variabel Independen (X) adalah variabel Rasio Profitabilitas dalam penelitian ini terdiri dari Operating Profit Margin $\left(X_{1}\right), N e t$ Profit Margin $\left(X_{2}\right)$, Return On Asset $\left(X_{3}\right)$, Return On Equity $\left(X_{4}\right)$ dan Earning Per Share $\left(X_{5}\right)$

$$
\text { Operating Profit Margin }
$$

(OPM)adalah kemampuan perusahaan dalam menghasilkan laba kotor dari pendapatan usaha perusahaan tersebut.Net Profit Margin (NPM) adalah kemampuan suatu perusahaan untuk menghasilkan laba bersih dari pendapatan suatu perusahaan tersebut.Return on assets (ROA) merupakan hasil perbandingan antara laba bersih setelah pajak dan total aktiva. Return On Equity (ROE) merupakan hasil perbandingan antara laba bersih setelah pajak dan total ekuitas.Earning Per Share (EPS) adalah laba per lembar saham yang diperoleh perusahaan.Harga saham adalah nilai atau jumlah uang yang dibutuhkan untuk membeli satu lembar saham tertentu. Harga saham merupakan closing price (CP) atau harga penutupan yang tercantum pada akhir tahun pada laporan keuangan perusahaan. Closing price adalah harga yang diminta oleh penjual atau pembeli pada saat akhir hari bursa.

\section{Populasi dan Sampel}

Teknik pengambilan sampel dalam penelitian ini menggunakan metode Total Sampling dimana sampel yang diambil adalah keseluruhan jumlah populasi dari perusahaan rokok yang terdaftar di Bursa Efek Indonesia periode tahun 2007 s/d 2010. Adapun perusahaan rokok yang dijadikan sebagai populasi dan sampel dalam penelitian ini adalah PT Hanjaya Mandala Sampoerna, Tbk, PT Bentoel Internasional Investama, Tbk dan PT Gudang Garam, Tbk.

\section{Metode Pengumpulan Data}

Teknik yang digunakan untuk memperoleh data selama penelitian adalahPenelitian Lapangan yaitu suatu teknik pengumpulan data dengan cara mengadakan penelitian atau pengamatan secara langsung kepada objek penelitian. Adapun cara yang digunakan adalah a) dokumentasi yaitu pengumpulan data dengan cara mencatat dari dokumendokumen yang terdapat dari lembaga atau instansi terkait yaitu dari Pusat Informasi Pasar Modal (PIPM) Cabang Balikpapan dan Bursa Efek Indonesia, b) kepustakaan (library Research) yaitu pengumpulan data sekunder dengan mengadakan riset yang berhubungan dengan konsep teori untuk menunjang keilmiahan dari penelitian ini, dengan mengutip beberapa teori yang dikemukakan beberapa ahli.

\section{Alat Analisis dan Pengujian Hipotesis}

Teknik analisis dalam penelitian ini adalah analisis kuantitatif. Analisis Regresi Linier Bergandadigunakan untuk mengetahui besarnya pengaruh variabelvariabel yaitu operating profit margin, net profit margin, return on asset, return on equity dan earning per share terhadap harga saham pada perusahaan rokok yang terdaftar di Bursa Efek Indonesia dengan menggunakan rumus:

$$
\begin{aligned}
Y= & \mathbf{a}+\mathbf{b}_{1} X_{1}+\mathbf{b}_{2} X_{2}+b_{3} X_{3}+b_{4} X_{4} \\
& +b_{5} X_{5}+e_{i}
\end{aligned}
$$

Dimana :

$\mathrm{a} \quad=$ Konstanta

$\mathrm{b} \quad=$ Koefisien Regresi

$\mathrm{Y}=$ Harga Saham 
$\mathrm{X}_{1}=$ Operating Profit Margin (OPM)

$\mathrm{X}_{2}=$ Net Profit Margin (NPM)

$\mathrm{X}_{3}=$ Return On Assets (ROA)

$\mathrm{X}_{4}=$ Return On Equity (ROE)

$\mathrm{X}_{5}=$ Earning Per Share (EPS)

$\mathrm{e}_{\mathrm{i}}=$ Koefisien pengganggu

Uji regresi simultan (bersama-sama) atau $\mathrm{F}$ test digunakan untuk menguji pengaruhOperating Profit Margin, Net Profit Margin, Return on Asset, Return on EquitydanEarning Per Share secara bersama-sama memiliki pengaruh yang signifikan terhadap harga saham perusahaan rokok yang tercatat di Bursa Efek Indonesia. Dengan tingkat signifikansi yang digunakan $(\alpha)=5 \%$, atau dengan melihat probabilitas kesalahan kurang dari $5 \%$ pembuktiannya dengan membandingkan $F_{\text {hitung }}$ dan $F_{\text {tabel. }}$ Jika $F_{\text {hitung }}$ $>\mathrm{F}_{\text {tabel, }}$ hipotesis diterima. Jika $\mathrm{F}_{\text {hitung }}<$ $\mathrm{F}_{\text {tabel, }}$ hipotesis ditolak.

Uji regresi parsial atau t-test untuk melakukan uji pengaruh variabel independen dan variabel dependen secara parsial, maka masing-masing akan dilakukan uji-t. Dengan tingkat signifikansi yang digunakan $(\alpha)=5 \%$, atau probabilitas kesalahannya kurang dari 5\% pembuktiannya dengan membandingkan $t_{\text {hitung }}$ dan $t_{\text {tabel. Jika }} t_{\text {hitung }}$ $>\mathrm{t}_{\text {tabel, }}$ maka hipotesis diterimaJika $\mathrm{t}$ hitung $<\mathrm{t}_{\text {tabel, }}$ maka hipotesis ditolak.

\section{Analisis Hasil Penelitian}

\section{Analisis Hasil Regresi Linier Berganda}

Analisis ini bertujuan untuk menentukan hubungan variabel bebas terhadap variabel terikat, dengan menggunakan sofware SPSS versi 17 didapatkan hasil yang dirangkum dalam Tabel 1. Dari hasil analisis statistik tesebut diperoleh persamaan regresi sebagai berikut:

$$
\begin{aligned}
& Y=-589.180+0,221 X_{1}-0,348 X_{2}+ \\
& 0,049 X_{3}-0,012 X_{4}+0,915 X_{5}
\end{aligned}
$$

Berdasarkan persamaan diatas dapat dinyatakan pula bahwa variabel OPM, ROA dan EPS bertanda positif berarti ketiga variabel tersebut mempunyai pengaruh searah terhadap harga saham, yakni peningkatan variabel diatas diikuti pula peningkatan harga saham itu sendiri sedangkan untuk NPM dan ROE yang bertanda negatif ini menandakan bahwa variabel tersebut mempunyai pengaruh yang berlawanan terhadap harga saham yaitu peningkatan pada NPM dan ROE maka harga saham akan mengalami penurunan dan sebaliknya.

\section{Pengujian Hipotesis}

Uji Simultan (Uji F) untuk menguji hipotesis pertama yang menyatakan bahwa variabel rasio profitabilitas secara simultan berpengaruh terhadap harga saham pada perusahaan rokok yang terdaftar di Bursa Efek Indonesia. Hasil penelitian dengan tingkat signifikansi (level of significance) $5 \%$ ditunjukkan dalam Tabel 1 , di mana $\mathrm{F}$ hitung sebesar 29,735 dengan nilai signifikansi sebesar 0,000 yang berarti bahwa Hipotesis 1 diterima.

Uji Parsial (Uji t) dilakukan untuk menguji hipotesis kedua yang menyatakan bahwa variabel rasio profitabilitas secara parsial berpengaruh signifikan terhadap harga saham pada perusahaan rokok yang terdaftar di Bursa Efek Indonesia. Hasil penelitian dengan tingkat signifikansi (level of significance) 5\%menunjukkan bahwa dari 5 variabel, hanya 1 variabel yaitu EPS yang berpengaruh signifikan.

Analisis Pengaruh Operating Profit Margin (OPM) terhadap harga saham.Diperoleh $t_{\text {hitung }}$ sebesar 0,732 dengan nilai signifikansi 0,468 , maka dapat dikatakan bahwa Operating Profit Margin (OPM) tidak berpengaruh signifikan terhadap harga saham perusahaan-perusahaan rokok yang terdaftar di Bursa Efek Indonesia, adapun pengaruh OPM terhadap harga saham sebesar 0,221. Dengan demikian Hipotesis ditolak.

Analisis Pengaruh Net Profit Margin (NPM) terhadap harga sahamdiperoleh $t_{\text {hitung }}$ sebesar $-1,067$ dengan nilai signifikansi 0,292, maka dapat dikatakan bahwa Net Profit Margin (NPM) tidak berpengaruh signifikan terhadap harga saham perusahaan rokok yang terdaftar di 
Bursa Efek Indonesia. Dengan demikian Hipotesis ditolak.

Analisis Pengaruh Return On Assets (ROA) terhadap harga sahamdiperoleh $t_{\text {hitung }}$ sebesar 0,115 dengan nilai signifikansi 0,909 , maka dapat dikatakan bahwa Return On Assets (ROA) tidak berpengaruh signifikan terhadap harga saham perusahaan rokok yang terdaftar di Bursa Efek Indonesia. Dengan demikian Hipotesis ditolak.

Analisis Pengaruh Return On Equity(ROE) terhadap harga sahamdiperoleh $t_{\text {hitung }}$ sebesar $-0,033$ dengan nilai signifikansi 0,974, maka dapat dikatakan bahwa Return On Equity(ROE) tidak berpengaruh signifikan terhadap harga saham perusahaan rokok yang terdaftar di Bursa Efek Indonesia. Dengan demikian Hipotesis ditolak.

Analisis Pengaruh Earning Per Share (EPS) terhadap harga saham diperoleh $t_{\text {hitung }}$ sebesar $-9,218$ dengan nilai signifikansi 0,000, maka dapat dikatakan bahwa Earning Per Share (EPS) berpengaruh signifikan terhadap harga saham perusahaan rokok yang terdaftar di Bursa Efek Indonesia.Dengan demikian Hipotesis diterima.

\section{Kesimpulan}

Rasio profitabilitas yang terdiri dari operating profit margin, net profit margin, return on assets, return on equity dan earning per share secara simultan berpengaruh signifikan terhadap harga saham pada perusahaan rokok yang terdaftar di Bursa Efek Indonesia. Pengaruh rasio profitabilitas sebesar $78 \%$ dan sisanya $22 \%$ dipengaruhi oleh variabel lain di luar penelitian ini.

Rasio profitabilitas yang terdiri dari operating profit margin, net profit margin, return on assets, dan return on equity secara parsial tidak berpengaruh terhadap harga saham dan hanya earning per share yang berpengaruh secara siginifikan terhadap harga saham pada perusahaan rokok yang terdaftar di Bursa Efek Indonesia.

\section{Saran}

Berdasarkan hasil penelitian yang telah dilakukan, maka saran yang dapat diberikan antara lainbagi peneliti hasil penelitian rasio profitabilitas terhadap harga saham pada perusahaan rokok yang terdaftar di Bursa Efek Indonesia dapat dijadikan bahan kajian lebih lanjut berkaitan dengan manajemen keuangan dalam menjelaskan harga saham sehingga penelitian ini dapat dikembangkan dengan menggunakan rasio yang lain.Bagi investor yang memegang saham pada perusahaan rokok disarankan untuk mengurangi jumlah saham pada portofolio investasi.

\section{Daftar Pustaka}

Anoraga, Pandji, 2007.Pengantar Bisnis:Pengelolaan Bisnis dalam Era Globalisasi, Cetakan Pertama, Jakarta : Rineka Cipta. dan Pakarti

Piji, 2001. Pengantar Pasar Modal, Edisi Revisi, Jakarta : Rineka Cipta.

Brigham, Eugene F, 2005. Fundamental of Financial Management, Seventh Edition, Orlando : The Dryen Press.

Darmadji, M. dan M. Fakhrudin. 2001, Perangkat dan Model Analisis Investasi di Pasar Modal, Jakarta : Elex Media Komputindo

Harianto, Farid dan Siswanto Sudomo, 2001. Perangkat dan Analisis Investasi di Pasar Modal Indonesia. Jakarta: PT. Bursa Efek Jakarta.

Hampton, John J, 1997. Financial Decision Making : Concepts, Problems \& Sases, New Delhi : Prentice-Hall of India Limited.

Harahap, Sofyan, Syafri. 2007. Analisis Kritis atas Lapoan Keuangan. Jakarta : Raja Grasindo Persada. 
Husnan, Suad, 2010. Dasar-dasar Teori Portofolio dan Analisis Sekuritas, Edisi Kesembilan, Yogyakarta : UPP AMP YKPN.

Munawir, S, 1997, Analisa Laporan Keuangan, Edisi Keempat, Yogyakarta : Liberty.

Rusdin, 2006, Pasar Modal (Teori Masalah, dan Kebijakan dalam Prakti), Cetakan Pertama, Bandung : Alfabeta.
Sawir, Agnes, 2005, Analisis Kinerja Keuangan dan Perencanaan Keuangan Perusahaan, Jakarta : Gramedia Pustaka Utama.

Sekaran, U, 2003. Research Methods for Business : A Skill Building Approach $2^{\text {nd }}$ Edition, New York: John Wiley and Son.

Syamsuddin, Lukman, 2002, Manajemen Keuangan Perusahaan, Edisi Baru, Jakarta : Rajagrafida Persada. 